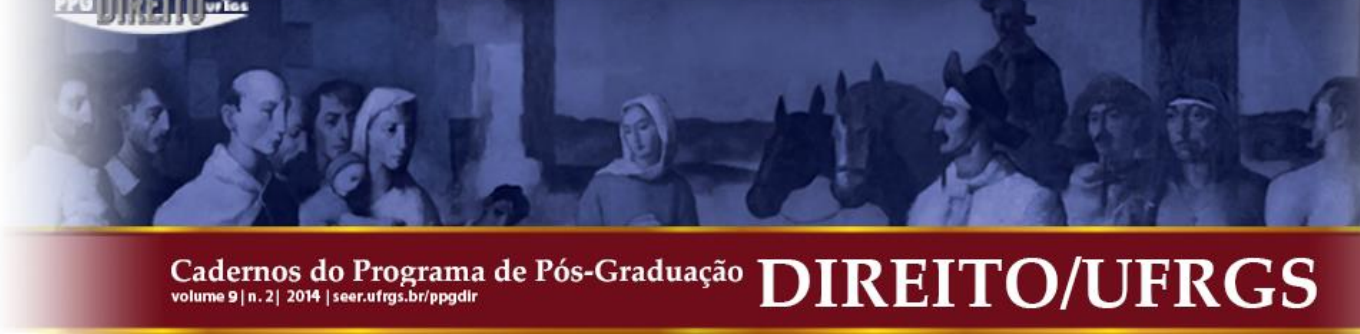

\title{
SÚMULAS VINCULANTES E FORÇA NORMATIVA: ASPECTOS CRÍTICOS
}

\author{
BINDING PRECEDENTS AND NORMATIVE POWER: CRITICAL ISSUES
}

\author{
Alice de Siqueira Khouri* \\ Fernando Horta Tavares $^{* *}$
}

\begin{abstract}
RESUMO: O presente estudo possui cerne no debate acerca da criação e aplicação das súmulas vinculantes em um contexto jurídico democrático e pretende, a partir das teorias de classificação normativa entre regras e princípios do cenário pós-positivista, alinhavar alguns aspectos críticos acerca de uma possível inconstitucionalidade da força normativa do instituto. Nesta direção, à luz do Direito Constitucional e de conceitos da Teoria do Direito, trazendo ainda o exemplo do enunciado da Súmula Vinculante 13, pretende-se aprofundar os estudos conteudísticos da temática sob o viés dos resultados obtidos a partir da ponderação prévia entre normas do ordenamento jurídico brasileiro, levando em conta as particularidades de um caso concreto que não passou pelo crivo do devido processo legislativo o qual, pelas suas particularidades, pode resultar na vinculação de futuros casos pretensamente semelhantes.
\end{abstract}

PALAVRAS-CHAVE: Súmula Vinculante; Inconstitucionalidade; Regras; Princípios; Pós-Positivismo; Ponderação.
ABSTRACT: This study has heart in the debate about the creation and application of binding precedents in a democratic legal context and aims, from the theories of normative classification between rules and principles of post-positivist scenario, identify and analyze some critical aspects about possible unconstitutionality of the normative force of the institute. In this direction, in the light of the Constitutional Law and the Legal Theory concepts, also bringing the example of the statement of Binding Precedent 13, it is intended to deepen the content studies of the theme from the perspective of the results obtained from previous balance among norms of the Brazilian legal order, taking into account the particularities of a case that did not pass through the scrutiny of due process of law which, by its characteristics, can result in the binding of future cases allegedly similar.

KEYWORDS: Binding Precedent; Unconstitutionality; Rules; Principles; Post Positivism; Balancing Procedure.

SUMÁRIO: Introdução. 1. Súmula vinculante: definição, origem e crítica acerca da sua constitucionalidade. 2. Súmula vinculante enquanto norma jurídica: relação entre princípios e regras jurídicas. 3. Dimensão normativa das súmulas vinculantes e o caso paradigmático do enunciado da súmula n. 13. Considerações finais. Referências.

\section{INTRODUÇÃO}

A respeito da existência das súmulas vinculantes no ordenamento jurídico brasileiro talvez o aspecto mais criticado seja o seu efeito vinculante na medida em que torna seu conteúdo de observância obrigatória para todos os órgãos do Judiciário e da Administração Pública.

Vê-se, assim, que no que tange ao aspecto de sua força vinculante, para que a súmula tenha peso de força normativa que lhe foi atribuída por meio da Lei $n^{\circ} 11.417 / 06$, se faz

\footnotetext{
* Bacharel em Direito pela Pontifícia Universidade Católica de Minas Gerais. Pesquisadora do Instituto de Investigação Científica Constituição e Processo. Advogada.

*** Doutor em Direito e Mestre em Direito Processual pelo Programa de Pós-Graduação em Direito da Pontifícia Universidade Católica de Minas Gerais. Professor Adjunto da Universidade Federal de Juiz de Fora. PósDoutoramento em Direito Constitucional pela Faculdade de Direito da Universidade Nova de Lisboa. Presidente do Instituto de Investigação Científica Constituição e Processo. Advogado.
} 


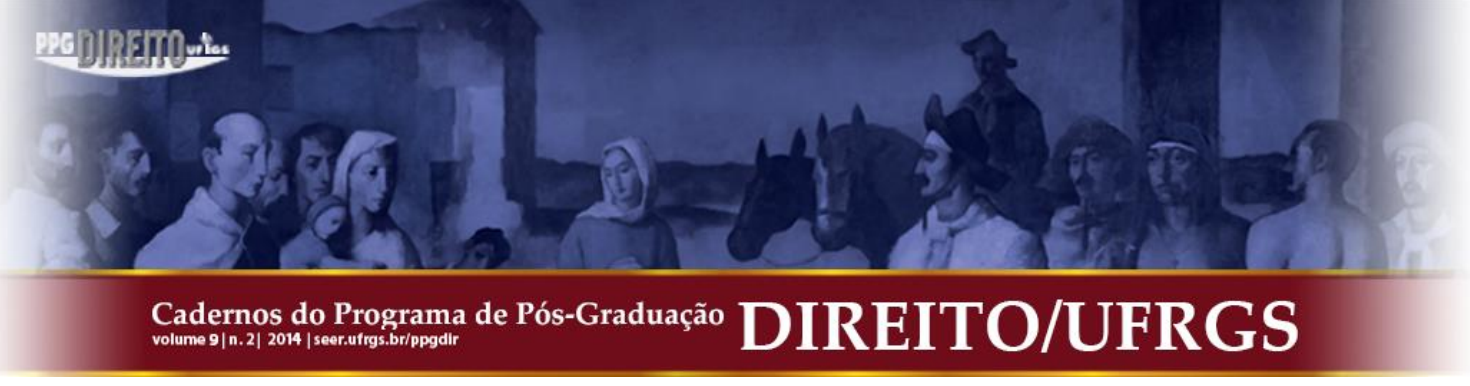

presente o debate pela inconstitucionalidade das súmulas vinculantes. Assim, enquanto parte da doutrina defende a sua existência com base em princípios de segurança jurídica, economia e celeridade processual, frisando a importância atual do papel do Judiciário na efetivação dos direitos fundamentais, outra parte, por sua vez, alerta para a clara violação ao princípio da separação das funções estatais (que a Constituição chama de "separação de poderes"), da independência dos órgãos judiciais, do devido processo constitucional, dentre outros.

Dentre alguns doutrinadores ${ }^{1}$ que defendem a constitucionalidade da súmula vinculante, vê-se que os argumentos mais utilizados são a consecução de certos princípios basilares e essenciais no Estado de Direito tais como a segurança jurídica, igualdade e celeridade processual. Sob a ótica dessa corrente doutrinária favorável à súmula, a mesma é importante e eficaz como mecanismo de garantir "às normas jurídicas uma interpretação única e igualitária” (MORAES, 2006, p. 1534).

Em dissonância na doutrina, estão aqueles que se valem, além dos argumentos acerca do engessamento das decisões judiciais provocado pelas súmulas vinculantes na medida em que retiram a possibilidade de julgamento independente pelas instâncias inferiores, do fato de o rol de legitimados a aprovação, revisão ou cancelamento da súmula é algo extremamente limitado, o que é notadamente um fator antidemocrático. Como exemplo, destacam-se as lições de Dalmo de Abreu Dallari (2010) e, no mesmo sentido doutrinário, Luiz Flávio Gomes (1997) e Kildare Carvalho (2008) ${ }^{2}$.

\footnotetext{
${ }^{1}$ A exemplo da doutrina que defende a constitucionalidade da súmula vinculante está Alexandre de Moraes, que diz: "As súmulas vinculantes surgem a partir da necessidade de reforço à idéia de uma única interpretação jurídica para o mesmo texto constitucional ou legal, de maneira a assegurar-se a segurança jurídica e o princípio da igualdade, pois os órgãos do Poder Judiciário não devem aplicar as leis e os atos normativos aos casos concretos de forma a criar ou aumentar desigualdades arbitrárias, devendo, pois, utilizar-se de todos os mecanismos constitucionais no sentido de conceder às normas jurídicas uma interpretação única e igualitária". MORAES, 2006, pp. 1534-1535. No mesmo sentido, Oscar Corrêa assevera que: "O inaceitável é que se decida e redecida, inúmeras vezes, na Corte Superior (final) a questão, sem recurso possível, e continuem os juízos inferiores a decidir contrária e diversamente, forçando as partes à continuação da litigância processual, com os ônus e retardamentose e os mais prejuízos que acarreta. E, sobretudo, abarrotando de casos de conhecida solução as prateleiras dos juízos, com prejuízo de todos os jurisdicionados”. CORRÊA, 2000, p. 158.

2 Luiz Flávio Gomes leciona, a respeito desse ponto, que: "Na verdade, independência judicial e súmula vinculante são inconciliáveis. Uma afasta a outra. São termos aporéticos. Urge a descoberta de alguma solução diferente para o problema dos Tribunais, sem que se tenha que pagar um preço inusitado (qual seja, o fim da independência dos juízes). A rebelião ou revolta ou irresignação dos juízes contra a súmula vinculante não pode, segundo um equivocado ponto de vista, ser encarada como manutenção de algum privilégio, defesa dos direitos pessoais, corporativismo, 'ativismo judicial' que só desacredita a Justiça, relutância infundada ou uma 'tola discussão sobre a liberdade hermenêutica e decisória do juiz'. Essa é uma visão incorreta da independência judicial, que existe para a garantia do próprio Estado Constitucional e Democrático de Direito. Urge compreender que é da essência da independência da função de julgar (que é expressão da soberania estatal) a possibilidade de interpretar o texto jurídico imaginando para a solução do caso concreto. Retirada essa
} 


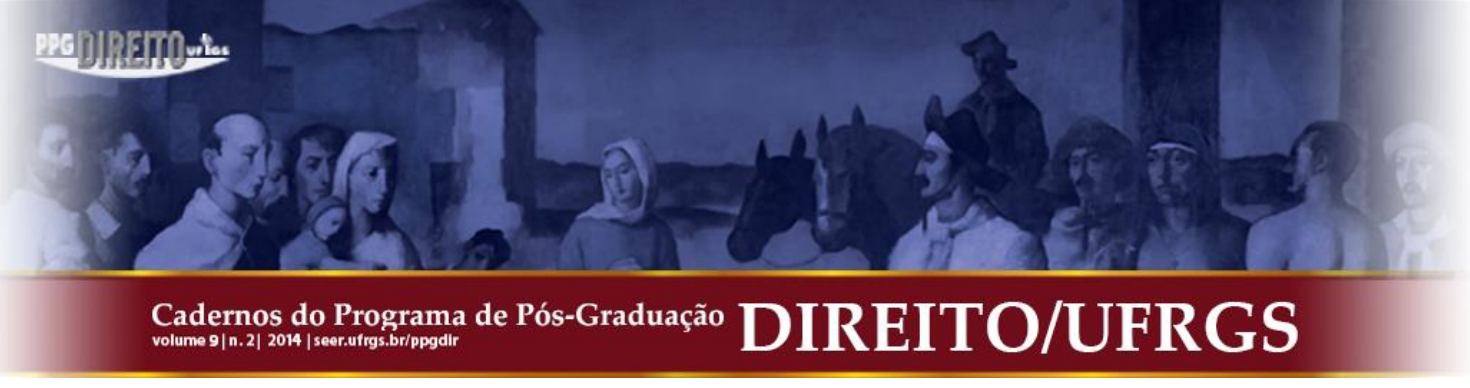

Nesse contexto de intenso debate doutrinário, brevemente exposto e narrado acima, se a súmula vinculante tem "força de lei”, em consonância inclusive com a etimologia trazida em seu nome, seria ela então uma espécie de norma? E, enquanto norma seria, dentro das teorias formuladas por Robert Alexy e Ronald Dworkin, regra, ou, em verdade, um princípio? Poderia assumir as duas conotações?

Essas indagações conduzem a uma aplicação das teorias clássicas que surgiram no contexto pós-positivista, no qual regras e princípios são espécies normativas cuja diferenciação configura-se importante na aplicação e interpretação do Direito, ao lado de conceitos como ponderação entre normas e a argumentação como justificação do ato decisório. Assim, a partir de tais elementos propedêuticos, sugere-se a existência de mais um aspecto de inconstitucionalidade das súmulas vinculantes a partir da sua aplicação: o engessamento de futuras situações pretensamente semelhantes a partir da ponderação entre normas jurídicas casuisticamente realizadas, em muitos casos, pelo Supremo Tribunal Federal.

\section{SÚMULA VINCULANTE: DEFINIÇÃO, ORIGEM E CRÍTICA ACERCA DA SUA CONSTITUCIONALIDADE}

Em breve síntese inaugural do raciocínio a ser desenvolvido neste artigo, define-se súmula vinculante como o enunciado proferido pelo Supremo Tribunal Federal no contexto do controle difuso de constitucionalidade, ao qual se atribui a imperatividade de subordinar ao seu conteúdo todos os atos a serem praticados por quaisquer dos chamados Poderes Executivo, Judiciário e os órgãos da Administração Pública, direta ou indireta, de todos os entes que compõem a Federação.

Referido instituto, da maneira como existe atualmente, foi introduzido no ordenamento jurídico brasileiro pela Emenda Constitucional n. 45/2004, que acrescentou o

autonomia do juiz, subordinando-o ao mesmo tempo a um entendimento pré-configurado único, já não é preciso um 'juiz' para julgar a causa: um funcionário qualquer é quantum satis para carimbá-la, dando-lhe asolução estampada na súmula." GOMES, 1997, p. 15. No mesmo sentido, importante a crítica de Kildare Carvalho ao aspecto vinculante das súmulas: “(...) a súmula vinculante possibilita que o Supremo Tribunal Federal defina o alcance, em abstrato, das normas editadas pelo Congresso Nacional, cujos efeitos irão atingir não só os litigantes, mas a sociedade em geral, comprometendo o próprio objeto do ato legislativo, a lei, esta sim, de caráter geral, abstrato e obrigatório. Por isso é que a súmula vinculante contraria o princípio da separação de poderes, já que é da competência do Poder Legislativo a função de legislar.” CARVALHO, 2008, p. 526. 


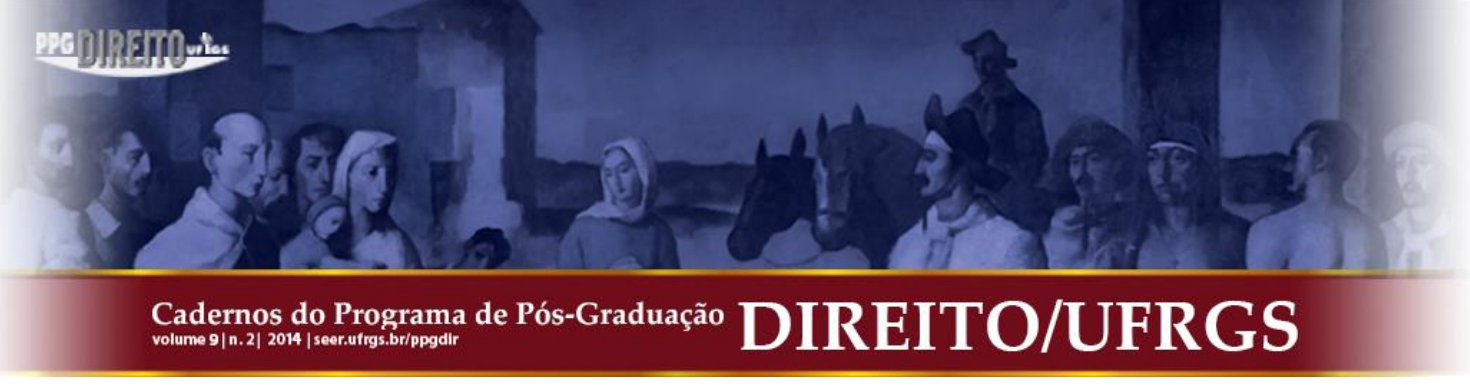

art. 103-A ao texto constitucional e, posteriormente, fora regulamentado pela Lei $\mathrm{n}^{\mathbf{0}}$ 11.417, de 19 de dezembro de 2006. A proposta do constituinte derivado era, então, de vincular a experiência constitucional brasileira a critérios de homogeneidade, segurança, celeridade e simplificação.

Diz o mencionado artigo:

Art. 103-A. O Supremo Tribunal Federal poderá, de ofício ou por provocação, mediante decisão de dois terços dos seus membros, após reiteradas decisões sobre matéria constitucional, aprovar súmula que, a partir de sua publicação na imprensa oficial, terá efeito vinculante em relação aos demais órgãos do Poder Judiciário e à administração pública direta e indireta, nas esferas federal, estadual e municipal, bem como proceder à sua revisão ou cancelamento, na forma estabelecida em lei. (Incluído pela Emenda Constitucional no 45, de 2004)(Vide Lei no 11.417, de 2006).

$\S 1^{\circ}$ A súmula terá por objetivo a validade, a interpretação e a eficácia de normas determinadas, acerca das quais haja controvérsia atual entre órgãos judiciários ou entre esses e a administração pública que acarrete grave insegurança jurídica e relevante multiplicação de processos sobre questão idêntica. (Incluído pela Emenda Constitucional no 45, de 2004)

$\S 2^{\circ}$ Sem prejuízo do que vier a ser estabelecido em lei, a aprovação, revisão ou cancelamento de súmula poderá ser provocada por aqueles que podem propor a ação direta de inconstitucionalidade. (Incluído pela Emenda Constitucional no 45, de 2004)

$\S 3^{\circ}$ Do ato administrativo ou decisão judicial que contrariar a súmula aplicável ou que indevidamente a aplicar, caberá reclamação ao Supremo Tribunal Federal que, julgando-a procedente, anulará o ato administrativo ou cassará a decisão judicial reclamada, e determinará que outra seja proferida com ou sem a aplicação da súmula, conforme o caso. (Incluído pela Emenda Constitucional no 45, de 2004)

Da leitura do dispositivo colacionado acima e do estudo acerca do surgimento das súmulas vinculantes no cenário jurídico brasileiro, vê-se a inspiração extraída do instituto do direito norte americano do stare decisis et quieta non movere, ou simplesmente stare decisis ${ }^{3}$ segundo o qual os juízes 'inferiores' devem, em seus novos julgados, manter a decisão dos juízes que lhes são hierarquicamente superiores quando decidirem sobre a mesma matéria.

Para tanto, a existência da súmula vinculante pressupõe reiteradas decisões sobre matéria constitucional e consubstancia-se na expressão do entendimento do Supremo Tribunal Federal, em linguagem prescritiva, a respeito da validade, interpretação e eficácia de determinadas normas.

Pode-se dizer que a súmula vinculante, portanto, é um compilado de precedentes unidos em função da natureza da controvérsia e da sua forma de solução. Ressalte-se que mesmo

\footnotetext{
${ }^{3}$ Expressão de origem latina que significa que não se deve alterar aquilo que jáfoi decidido, por homenagem àisonomia. Assim, deve-se buscar nos casos precedentes a decisão que foi aplicada, para utilizar como padrão nos casos idênticos que se sucederem. (Vide RE, 1990, p. 327).
} 


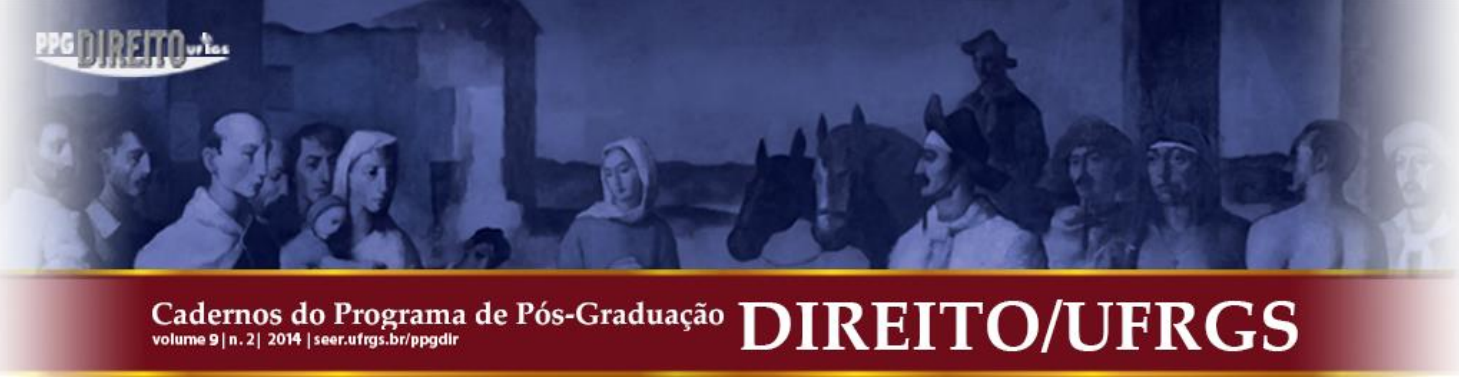

após a edição do texto da súmula, só será possível conceber aquilo que ela quer dizer após a análise de seus precedentes. Neste sentido, diz Gilmar Mendes:

Os limites objetivos da súmula vinculante são dados pelo enunciado que resulta de sua formação. É evidente que esse enunciado poderá ser mais bem compreendido à luz das referências da súmula, isso é, dos julgados que geraram a base para a decisão sumulada.

Assim, não raras vezes ter-se-á de recorrer às referências da súmula para dirimir eventual dúvida sobre o seu exato significado. Tais referências são importantes no que diz respeito à eventual distinção ou distinguishing que se tenha de fazer na aplicação da súmula vinculante. (MENDES, 2009, p. 1012)

Importante esclarecer, na direção da doutrina retro, que a correta compreensão do enunciado em súmula vinculante só se faz possível mediante análise conjugada: do compilado de jurisprudências que sustentam a súmula, da legislação, e dos princípios que subjazem àquele contexto. Por essas razões, acredita-se ser importante a discussão da existência de regras e princípios a nortear a discussão a respeito da aplicabilidade das sumulas vinculantes pois, com efeito, não pode a súmula ter força vinculante absoluta e ser sustentada por seus próprios enunciados de modo a ultrapassar a própria Lei e fazendo as suas vezes sem que antes se entenda a dimensão normativa da súmula.

Com relação a esse aspecto - alvo de maior crítica -, qual seja, a sua força normativa, há quem diga que a súmula vinculante se apresenta como verdadeira usurpação da tradicional atividade legislativa pelo poder judiciário ${ }^{4}$, na medida em que fere o princípio da separação de poderes e resulta em um “engessamento" das interpretações relativas à referida temática.

A exemplo da doutrina que critica fortemente a existência e aplicabilidade da súmula vinculante, veja-se a posição de Lenio Luiz Streck que se expressa da seguinte maneira:

Com o poder de editar súmulas, os Tribunais passam a ter um poder maior do que o Legislativo. Se se impedir que -das decisões exaradas em conformidade com as súmulas -sejam interpostos recursos, o Poder Judiciário estará acumulando as duas funções (legislativa e judiciária), petrificando o sentido do texto (e da norma exsurgente desse texto.) Daí que, examinando o sistema jurídico brasileiro como um paradoxo, é possível dizer que, do ponto de vista autopoiético, a vinculação sumular reforça o poder da auto reprodução do sistema. Com a vinculação, o STF "fecha" o sistema. (STRECK, 2005, p.113).

Gilmar Mendes (2009), por outro lado, na tentativa de justificar a legitimidade do instituto em debate, busca em Kelsen (1969, p. 115-116) a fundamentação teórica que embasa

\footnotetext{
${ }^{4}$ Questionável o instituto da súmula vinculante, sobretudo na medida em que tem poderes para conferir validade ànormas jurídicas mas, em verdade, faz mais que isso e, muitas vezes, cria novos conteúdos normativos. Neste sentido, o $\$ 1^{\circ}$ do artigo $103-\mathrm{A}$ da $\mathrm{CR} / 88$.
} 


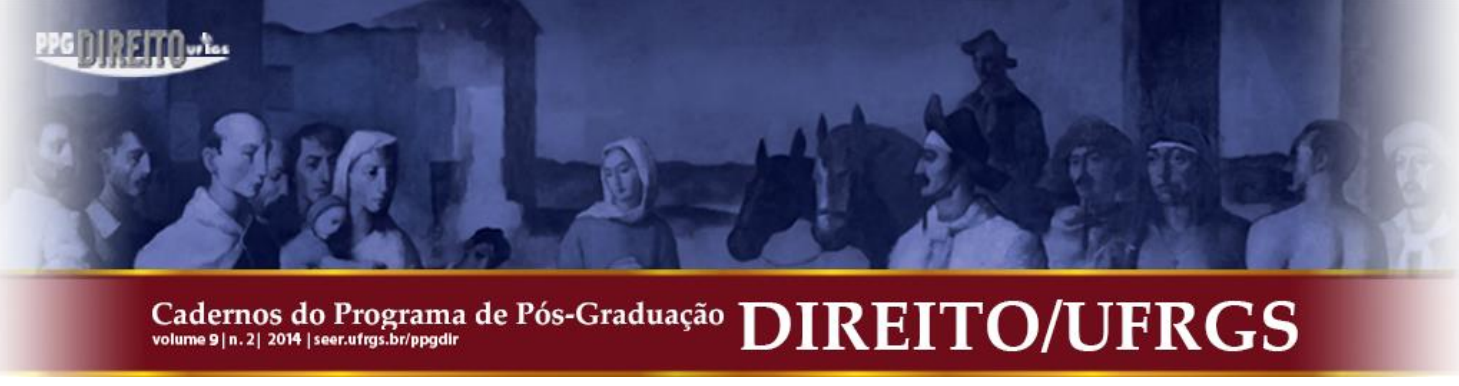

esta corrente de pensamento, afirmando que a função legislativa seria "inerente" ao poder judiciário, e não haveria, portanto, atividade atípica quando o Judiciário faz as vezes de legislador 5 .

Não obstante a diversidade de argumentos contra e a favor da constitucionalidade da súmula vinculante - que englobam questões importantes como a economia processual e celeridade trazidas pela ideia de uniformizar o entendimento jurisprudencial - há estranheza inevitável ao pensamento que defende a constitucionalidade do instituto. Isto porque, ainda que não sejam estagnadas, taxativas ou imutáveis as funções de cada um dos "poderes" legislativo, judiciário e executivo - existe, por questão de segurança jurídica e, principalmente legalidade, determinada função típica de cada um daqueles "poderes". É o que direciona o consagrado princípio republicano da "separação dos poderes" que, por mais que tido em várias discussões jurídicas como lugar comum, não pode ser ignorado em um Estado cujo Direito seja Democrático.

Assim, a função atípica do Judiciário inovar na ordem jurídica até pode se admitir (especialmente se fundada na hermenêutica dos direitos fundamentais), mas não é aceitável que seja catalogada como uma de suas funções típicas e comuns, como ocorre quando lhe é prevista a competência para editar permanentemente enunciados com "peso de lei".

Sabe-se que a tarefa interpretativa do Judiciário diante da necessidade de solucionar hard cases que, por sua própria concepção, são casos em que o ordenamento jurídico não prevê solução escrita e definitiva, é atividade que acaba por inovar, em certa medida, a ordem jurídica, isto é, de “criar" o Direito. No entanto, nesses casos é perfeitamente compreensível a realização dessa atividade que a princípio seria típica do Legislativo, por dois principais motivos: porque é atipicamente realizada pelo Judiciário (ainda que os hard cases sejam cada vez mais frequentes na contemporaneidade) e porque a tarefa interpretativa ${ }^{6}$, seja

\footnotetext{
${ }^{5}$ Acerca do tema, mencionando Kelsen e a concepção positivista que considera juízes como "legisladores delegados", vide CARVALHO NETTO, SCOTTI, 2011, p. 57-59.

${ }^{6}$ Mauro Cappelletti trata o assunto, afirmando que há alguns limites para a interpretação judiciária. Segundo o autor: "o reconhecimento de que éintrínseco em todo ato de interpretação certo grau de criatividade - ou, o que vem a dar no mesmo, de um elemento de discricionariedade e assim de escolha -, não deve ser confundido com a afirmação de total liberdade do intérprete. Discricionariedade não quer dizer necessariamente arbitrariedade, e o juiz, inevitavelmente criador do direito, não énecessariamente um criador completamente livre de vínculos (...) é verdade que existe, pelo menos, um baluarte extremo, digamos uma fronteira de bom senso, que se impõe tanto no caso da interpretação do case law, quanto no do direito legislativo, ao menos porque também as palavras têm um significado tão geralmente aceito que atéo juiz mais criativo e sem preconceitos teria dificuldade de ignorálo". Além desses limites, que o autor denomina substanciais, ele também cita outros, que seriam processais,
} 


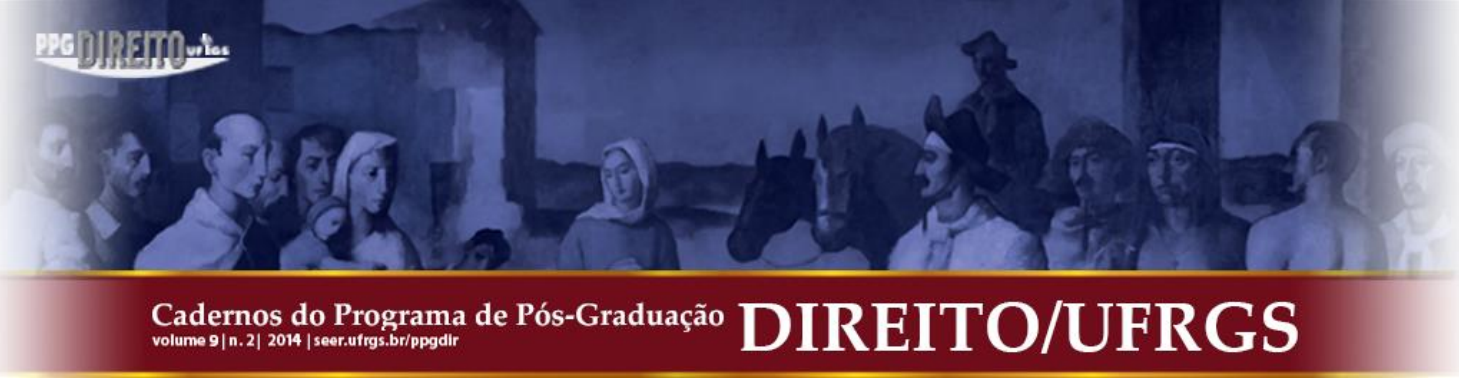

dentre outras, normas que outorgam competência a certos indivíduos para produzirem normas que por sua vez ditam o comportamento das pessoas, à qual o autor chama de Constituição.

$\mathrm{Na}$ esteira de como é tratado o tema acerca da existência e definição das normas jurídicas pode-se concluir sinteticamente, para os fins do presente artigo, que é por meio das normas jurídicas que o Ordenamento Jurídico dita a conduta permitida, proibida e obrigatória em determinada comunidade, historicamente situada.

A partir desse amplo conceito de norma, pode-se dizer que não somente pela força vinculativa de seu enunciado, mas principalmente por serem um enunciado prescritivo de natureza eminentemente jurídica - na medida em que pertencem ao ordenamento jurídico -, as súmulas vinculantes podem, nesta linha de raciocínio, serem classificadas como normas jurídicas.

Assim, dentro do contexto da constitucionalidade da súmula vinculante e as dúvidas, por consequência, de sua existência materialmente válida enquanto inovação da ordem jurídica sem o devido processo legiferante, encontra-se o debate pós-positivista acerca da classificação das normas jurídicas entre regras e princípios, iniciado na doutrina clássica por Ronald Dworkin, com a obra Levando os Direitos a Sério ${ }^{7}$, e, posteriormente, desenvolvido com as contribuições de Robert Alexy, dentre as quais destaca-se a Teoria dos Direitos Fundamentais $^{8}$. Referido debate doutrinário situa-se, como dito, em um contexto de falência do método puramente subsuntivo e inaugurado pela nova hermenêutica constitucional, e as lições das mencionadas obras contribuem muito para a aqui pretensa análise discursiva do conteúdo trazido, em geral, pela temática das súmulas vinculantes.

Nessa direção, destaca-se que a percepção do estudioso do ordenamento jurídico como um sistema híbrido em termos de normas diferentes entre si, de aplicação e conteúdo diversos, e, nesse sentido, a valorização dos Princípios como possibilidades de maior efetividade aos direitos fundamentais, os quais, a seu turno, conferiram importância ao debate pós-positivista supramencionado, na qual a doutrina cuidou de apresentar definições quanto a regras e a princípios $^{9}$.

\footnotetext{
${ }^{7}$ DWORKIN, 2002.

${ }^{8}$ ALEXY, 2008.

${ }^{9}$ Como bem pontua Thomas Bustamante, "Entre outras razões, essa classificação é metodologicamente relevante porque implica uma diferença quanto ao modo de aplicação das duas classes de normas. Enquanto os princípios devem ser otimizados segundo a máxima da proporcionalidade para que sejam determinadas as possibilidades fáticas e jurídicas em que eles devem ser aplicados, de sorte que a operação básica de sua aplicação é a
} 


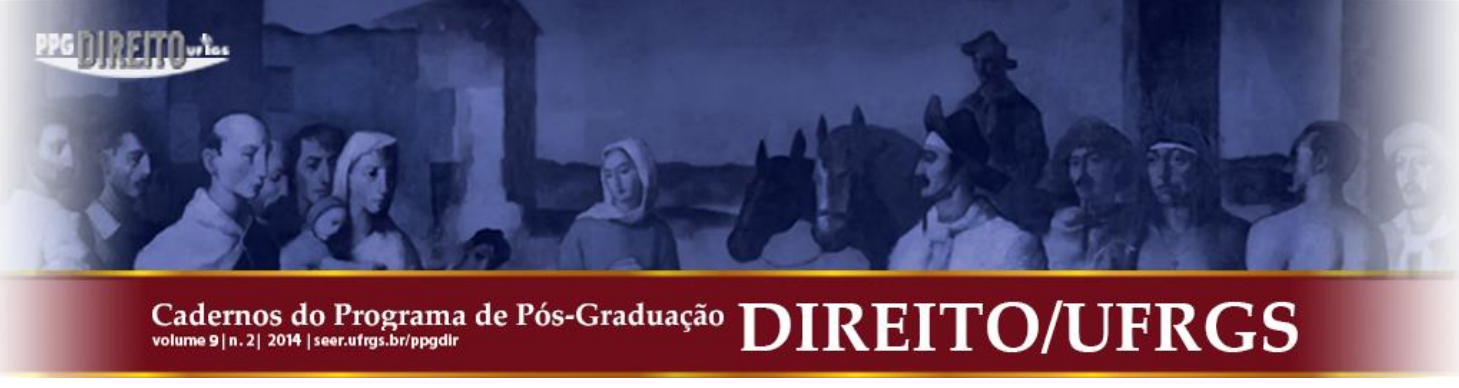

Reconhecendo a importância da classificação normativa ofegada pela doutrina tradicional, principalmente no que concerne ao âmbito de aplicação das normas existentes e na tarefa argumentativa quando dessa aplicação, inevitável se faz a remissão aos estudos de classificação e importância das normas jurídicas.

Segundo Robert Alexy $(2008)^{10}$, princípios "são normas que ordenam que algo seja realizado na maior medida possível dentro das possibilidades jurídicas e fáticas existentes”, sendo, portanto, mandados de otimização que podem ser cumpridos em graus diferentes, a depender do caso concreto e variável entre as inúmeras possibilidades fáticas e jurídicas variáveis e infinitas.

As regras, lado outro, são normas de caráter pretensamente definitivo, estabelecem condutas específicas a serem seguidas diante de pré-determinado contexto e, assim, "são normas que são sempre ou satisfeitas ou não satisfeitas" ${ }^{11}$. Por serem mais específicas e determinarem condutas descritivas, a sua incidência se dá pelo método subsuntivo: subsunção da situação, do caso concreto, à regra. A seu turno, os princípios são aplicados por um método ponderativo, no qual certos aspectos são ponderados conduzindo a melhor aplicação de determinado princípio ao caso.

Em um sistema jurídico complexo, tal qual é o brasileiro, coexistem, em uma perspectiva hermenêutica e pragmática na interpretação do Direito, regras e princípios, sendo aquelas primeiras as normas definidoras de condutas específicas, e os princípios como fins a serem cumpridos em intensidade variável.

No contexto de uma classificação normativa racionalizada, Alexy ainda defende a interdependência ${ }^{12}$ entre regras e princípios na medida em que vincula a teoria dos princípios ao discurso prático: regra é resultado de uma opção legislativa de uma ponderação de princípios que estão por trás de seu enunciado e são responsáveis por, em seu conteúdo determinante, conferir maior eficácia aos fins de determinado princípio. Por sua vez, os princípios quando colidentes podem ser resolvidos por meio de regras que estabeleçam

ponderação, as regras contêm mandados definitivos e a operação básica para sua aplicação é a subsunção.” (BUSTAMANTE, 2010, p. 154).

${ }^{10}$ ALEXY, 2008, p. 90.

${ }^{11}$ ALEXY, 2008. p. 92.

${ }^{12}$ Segundo Thomas Bustamante, essa interdependência se assemelha a relação de precisão entre as normas diretamente estatuídas na Constituição e as normas adscritas, medida em que as primeiras conferem fundamento de legitimidade as segundas, e essas, por sua vez, garantem maior aplicabilidade e efetividade das primeiras. (BUSTAMANTE, 2010, p. 155.) 


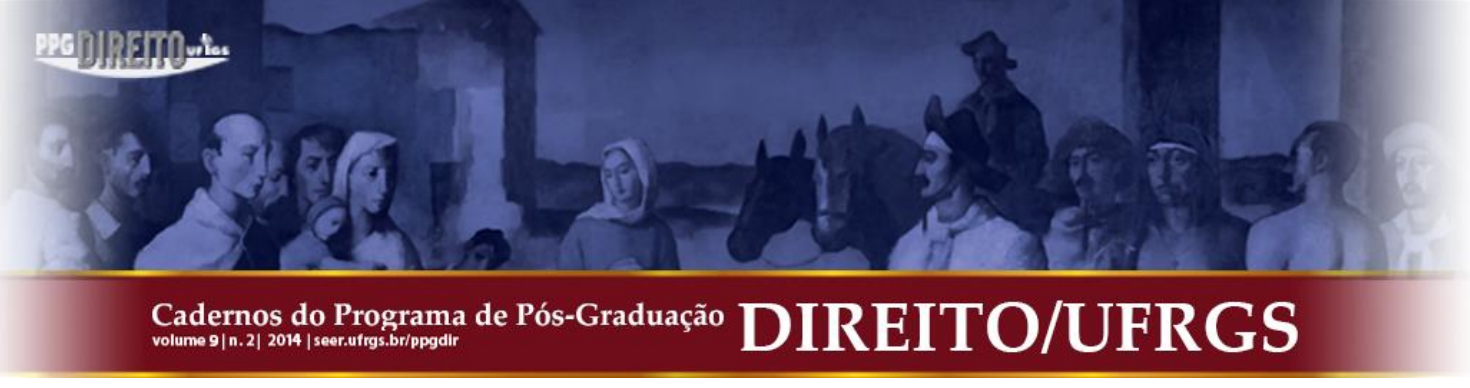

soluções prioritárias em seu conteúdo. Tem-se, portanto, que o ordenamento jurídico tem como uma de suas características a coexistência interdependente de regras e princípios.

Feita essa brevíssima introdução a partir das lições da doutrina clássica a respeito da existência e definição de regras e princípios enquanto espécies normativas, passa-se a analisar a dimensão normativa das súmulas vinculantes, considerando a possibilidade de serem consideradas princípios ou regras e em que medida essa classificação normativa auxilia na verificação da legitimidade do seu enunciado com efeito vinculante.

\section{DIMENSÃO NORMATIVA DAS SÚMULAS VINCULANTES E O CASO PARADIGMÁTICO DO ENUNCIADO DA SÚMULA N. 13}

De acordo com o artigo 103-A da Constituição, as súmulas têm efeito vinculante para os poderes judiciário e executivo e demais órgãos da Administração Pública direta e indireta, de todos os níveis federativos. Em verdade, vê-se que a todos a súmula obriga, pois, sabendo serem vinculantes para os referidos poderes, todos, na hipótese e a priori, procurarão desenvolver suas atividades em obediência aos conteúdos sumulares, por compreender que sua violação poderá ocasionar discussões a serem levadas a debate perante os órgãos judiciais e, por vezes, a imposição de sanções ${ }^{13}$. Esse caráter geral nada mais é do que a principal característica das súmulas para conferir-lhes status de norma, como já anteriormente mencionado, com destinatário geral e, a princípio, indefinido, à exceção do poder legislativo, cuja a atividade se encaixa no equilíbrio moldado pelo princípio republicano da separação das funções estatais.

Sabe-se que, quanto à hipótese de incidência, as normas são classificadas como abstratas ou concretas (BOBBIO, 1999). São concretas aquelas normas que se referem em sua hipótese de incidência a uma situação concreta, histórica e específica. São abstratas, por sua vez, as normas que se referem às hipóteses e não a fatos concretos. (BOBBIO, 1999, p. 27)

\footnotetext{
${ }^{13}$ Interessante, neste aspecto, os estágios de Kohlberg, que refletem as razões pelas quais a comunidade segue regras, mencionado por Menelick de Carvalho Netto e Guilherme Scotti (KOHLBERG apud CARVALHO NETTO; SCOTTI, 2011, p. 84-86). Segundo os autores que citam Kohlberg, o positivismo estaria no estágio 4 da fase Convencional (na qual o comportamento correto consiste em cumprir um dever e manter a ordem social), enquanto a teoria de Dworkin pressupõe o estágio 6, Pós-Convencional (a orientação se dá pelo reconhecimento de princípios éticos universais).
} 


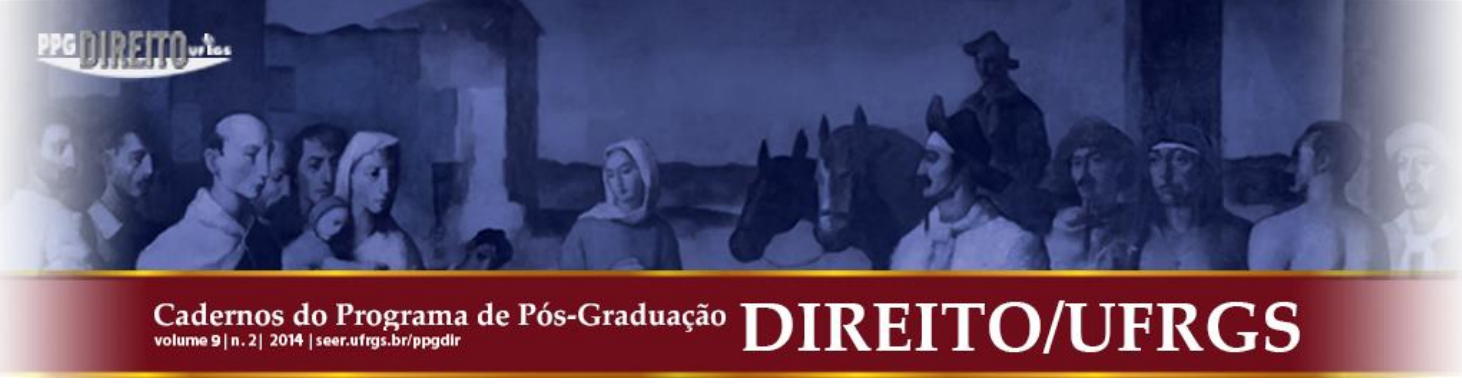

De acordo com a previsão constitucional do artigo 103-A, a súmula se aplica à hipótese de ocorrer controvérsia atual a respeito de validade, interpretação ou eficácia de normas ${ }^{14}$, entre órgãos judiciais ou entre esses e a administração pública que acarrete grave insegurança jurídica e relevante multiplicação de processos relativos a questão idêntica, para usar a linguagem da Constituição. Prevê, portanto, a uniformização de debate acerca de questão hipotética de largo alcance de controvérsia entre normas e não apenas visa solucionar uma controvérsia concreta entre norma determinada (no singular), sendo, assim, por seu impacto, verdadeiro resultado do controle de constitucionalidade concentrado. Logo, a princípio, em razão do maior arco discursivo que se quer alcançar, as súmulas são prescrições abstratas aplicando-se a todas as situações futuras que estiverem em sua hipótese de incidência.

Por meio da classificação normativa pelo critério da generalidade, considerando a pretensão de largo horizonte hermenêutico de abstração inicial, seria possível enquadrar as súmulas vinculantes como normas do tipo princípio. No entanto, à vista da própria teoria de Alexy ${ }^{15}$, o critério de generalidade não é suficiente para a classificação normativa proposta por ele, que deixa claro em suas lições que o ponto nuclear da diferença entre regras e princípios tem como ponto central o contexto de aplicação. Assim, enquanto princípio, a aplicação se dá no âmbito da ponderação, e as regras, no da subsunção.

Essa insuficiência do critério da generalidade (abstração ou concretude) e a questão da aplicação remetem a uma necessidade de analisar o conteúdo de cada súmula vinculante, não sendo possível, portanto, uma classificação uníssona que enquadre-as apenas ou como princípios ou como regras.

Entende-se como mais acertado, no sentido de oferecer uma tentativa classificatória, que seja apreciado o conteúdo trazido pela redação da súmula, considerando a direção de seu enunciado, os termos utilizados e o contexto de incidência que procura determinar, e, caso haja uma prescrição de conduta, com hipótese de incidência e resultado específico, estar-se-á diante de uma regra.

Parece ser perfeitamente possível, portanto, adotar-se o raciocínio segundo o qual as súmulas vinculantes podem se comportar ora como princípio, ora como regra. Como exemplo

\footnotetext{
${ }^{14}$ Art. 103-A. O Supremo Tribunal Federal poderá, de ofício ou por provocação, mediante decisão de dois terços dos seus membros, após reiteradas decisões sobre matéria constitucional, aprovar súmula que, a partir de sua publicação na imprensa oficial, terá efeito vinculante em relação aos demais órgãos do Poder Judiciário e à administração pública direta e indireta, nas esferas federal, estadual e municipal, bem como proceder à sua revisão ou cancelamento, na forma estabelecida em lei. (Incluído pela Emenda Constitucional no 45, de 2004).

${ }^{15}$ Acerca de regras e princípios e a teoria da colisão na já mencionada obra: ALEXY, 2008.
} 


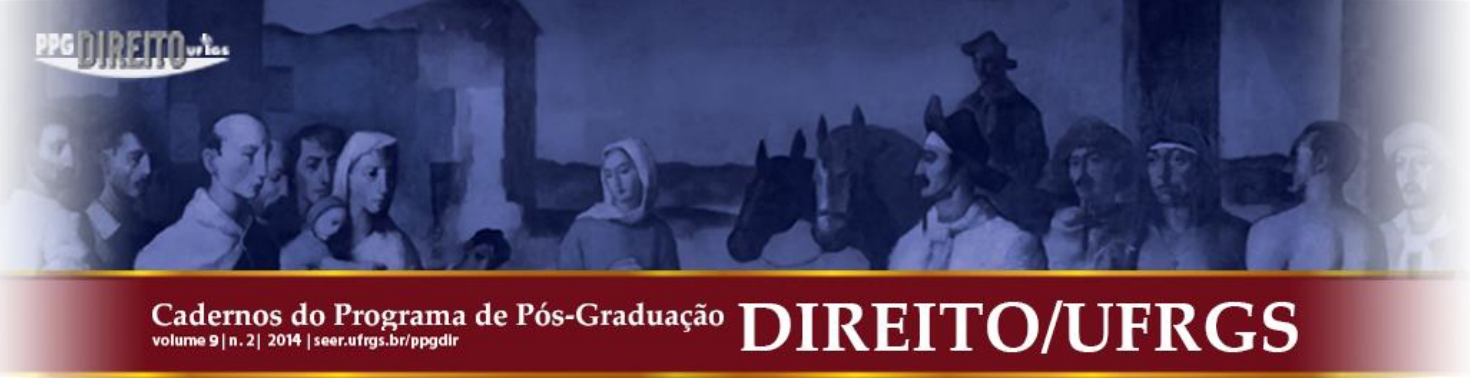

paradigmático, veja-se o enunciado da Súmula n. 13, editada pelo Supremo Tribunal Federal em 2008, verbis:

\begin{abstract}
A nomeação de cônjuge, companheiro ou parente em linha reta, colateral ou por afinidade, até o terceiro grau, inclusive, da autoridade nomeante ou de servidor da mesma pessoa jurídica investido em cargo de direção, chefia ou assessoramento, para o exercício de cargo em comissão ou de confiança ou, ainda, de função gratificada na administração pública direta e indireta em qualquer dos poderes da União, dos Estados, do Distrito Federal e dos Municípios, compreendido o ajuste mediante designações recíprocas, viola a Constituição Federal.
\end{abstract}

Na esteira do pensamento anteriormente construído, e à vista do texto da Súmula n. 13, parece não haver necessidade de muito esforço hermenêutico para perceber que as súmulas vinculantes podem se comportar ora como regras ora como princípios, dependendo de seu conteúdo. A partir da leitura da súmula supracolacionada pode-se dizer que o seu conteúdo diz respeito a uma determinação de conduta tida como proibida, específica, de âmbito de incidência determinado, qual seja, a nomeação de parentes para o exercício de cargo em comissão ou de confiança. Perfeitamente plausível a ideia do enquadramento da Súmula Vinculante 13 como regra, portanto.

Entretanto, é perceptível que o conteúdo da referida súmula revela uma ponderação prévia entre normas constitucionais, quais sejam: o princípio da moralidade expressamente previsto no artigo 37, da Constituição Brasileira de 1988, caput (moralidade latu sensu) e a regra constitucional escrita pelo mesmo artigo 37 que, no inciso II, permite a livre nomeação de cargo em comissão, hipótese a ser determinada pela Lei, ainda inexistente. Pela edição da súmula observa-se como resultado uma tentativa de ponderação a partir da prevalência do princípio da moralidade, concebido genericamente na sua própria condição de princípio.

Atualmente, a legislação brasileira, em seu artigo constitucional 37, II, faz menção aos cargos de livre nomeação e exoneração, reconhecendo a existência, e, portanto, juridicidade, das indicações aos cargos em comissão. No entanto, no que pese o dispositivo, não há qualquer outra norma a respeito do assunto, limitando ou restringindo a conduta do administrador na nomeação dos referidos cargos. E, ressalte-se, a matéria é única e exclusivamente de Lei, nos termos claros do aludido dispositivo constitucional. É neste ponto que reside o grave vício formal de que sofre a súmula vinculante n. 13.

O que existe, de maneira a tentar colmatar a lacuna legislativa e em um ato que foge aos padrões que consagram as democracias republicanas, que é o Princípio da Separação e 
Independência dos Poderes (art. 2o., da Constituição brasileira), é a Súmula Vinculante 13, editada pelo Supremo Tribunal Federal, que, de maneira genérica e em uma atividade nitidamente legiferante (e, portanto, atípica), cuidou de vedar "a nomeação de cônjuge, companheiro ou parente em linha reta, colateral ou por afinidade, até o terceiro grau, inclusive, da autoridade nomeante ou de servidor da mesma pessoa jurídica investido em cargo de direção, chefia ou assessoramento, para o exercício de cargo em comissão ou de confiança, em qualquer dos Poderes da União, dos Estados, do Distrito Federal e dos Municípios".

A ausência de norma legal a regular os dispositivos constitucionais aplicáveis aos ocupantes dos cargos em comissão (art. 37, e incisos retro indicados) e a imperatividade que sobressai da vinculatividade do posicionamento do STF leva ao questionamento de qual seria o exato âmbito de aplicação do enunciado sumular, uma vez que a proibição precede a própria definição do nepotismo (que, a rigor, não existe).

Não obstante a impossibilidade de vincular todas as situações de incidência do caso concreto ao conteúdo da súmula, como explicitado acima, ressalte-se que a ponderação trazida pela súmula vinculante 13 evidencia a incoerência lógico-normativa do instituto da súmula vinculante em geral, pois a regra constitucional do artigo 37, II, é clara no sentido de dizer que apenas a Lei pode limitar a nomeação para cargos em comissão e, até que isto seja feito, esse ato de nomeação é livre e constitucionalmente válido, nos limites aqui expostos.

Mais do que uma tentativa de colmatar suposta anomia normativa, aludida súmula vinculante limita essa liberdade de atuação da administração pública, sem, contudo, ser derivada da exigência de aplicabilidade de dois princípios de ordem constitucional, o Princípio de Reserva de Lei e o Princípio do Devido Processo Legislativo.

Não se ignora, de maneira alguma, os contornos constitucionais aplicáveis à hipótese, e muito menos que os limites a essa liberdade estão delineados pelos próprios princípios enunciados pelo caput do artigo 37, dentre eles o da moralidade e impessoalidade, de observância obrigatória. Entretanto, a tarefa de aplicação dos princípios, principalmente quando dizem respeito à possibilidade de se enquadrar em norma de eficácia contida as situações que podem resultar em cercear ou afastar a aplicação de regra constitucional já existente (tal como a contida no artigo 37, inciso II da Constituição), deve ser realizada da maneira mais racional e consistente possível, contando com a árdua tarefa do ônus argumentativo para justificar a opção pela prevalência de um ou outro, sempre levando em 


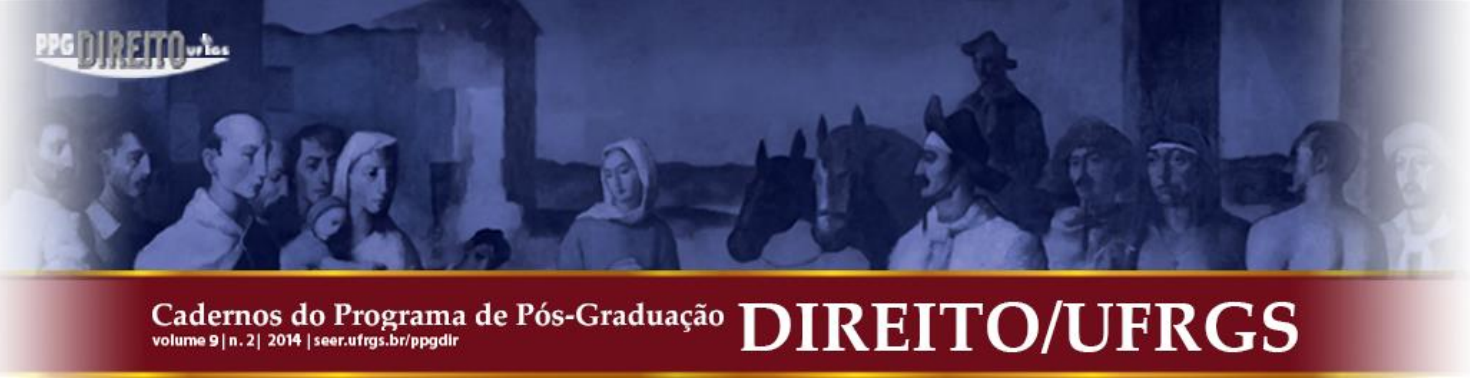

conta a sistematicidade do ordenamento jurídico, considerando, ainda, a força normativa da Constituição.

Sabe-se, como dito em momento anterior, que o Devido Processo Legal formata a atividade dos órgãos judiciários na aplicação do Direito, em procedimento moldado pelos princípios constitucionais do contraditório e da ampla defesa, que resultam na interpretação discursivamente democrática das normas. No entanto, ao proferir um ato decisório cujo cenário representa conflito (latu sensu) entre normas e, mais, de efeito vinculante tal como é o caso das súmulas ora em estudo, o Supremo Tribunal Federal exerce uma tarefa igualmente ponderativa a qual, a seu turno, necessariamente atrai o ônus argumentativo em sua pretensão de consistência e logicidade sistemático-normativa, requisitos de controle do ato decisório para que evite sua transfiguração em arbitrário como, aliás, exige o princípio da fundamentação das decisões definido pelo inciso IX, do artigo 93, da Constituição Brasileira.

No entanto, em linha contrária ao que foi exposto acima, percebe-se que, por vezes, na edição de súmulas vinculantes não há essa preocupação de justificação ou de apresentação dos critérios que nortearam a ponderação exercida, não havendo a explicitação de razões pelas quais se afasta este ou aquele princípio ou regra, quando da criação de determinado enunciado. Esse ônus argumentativo às vezes se coloca quando do julgamento de determinado caso, criador de um julgado que mais tarde será utilizado em casos futuros, sem considerar, contudo, que as peculiaridades do caso concreto - possibilidades fáticas e jurídicas - podem ser extremamente variáveis e, portanto, conduzir a soluções diferentes. Assim, a argumentação utilizada para justificar a ponderação entre normas realizada em uma situação determinada, não necessariamente pode ser utilizada em outra situação, ainda que semelhante.

Tem-se, portanto, grave problema jurídico que macula a pretensa constitucionalidade do instituto jurídico ora em exame: as súmulas vinculantes gozam de um status de norma, se comportando ora como princípio, ora como regra, mas são, conforme a tese defendida neste artigo, decisões que refletem uma ponderação prévia e nem sempre contam com a justificação argumentativa na construção da referida atividade ponderativa, na linha de entendimento esposada pela teoria de Robert Alexy e acabam gravitando no ordenamento jurídico desconectadas contextualmente de regras e princípios já existentes e, pior, engessando situações futuras pretensamente semelhantes sem o crivo do Devido Processo Legislativo, uma exigência inafastável da Democracia. 


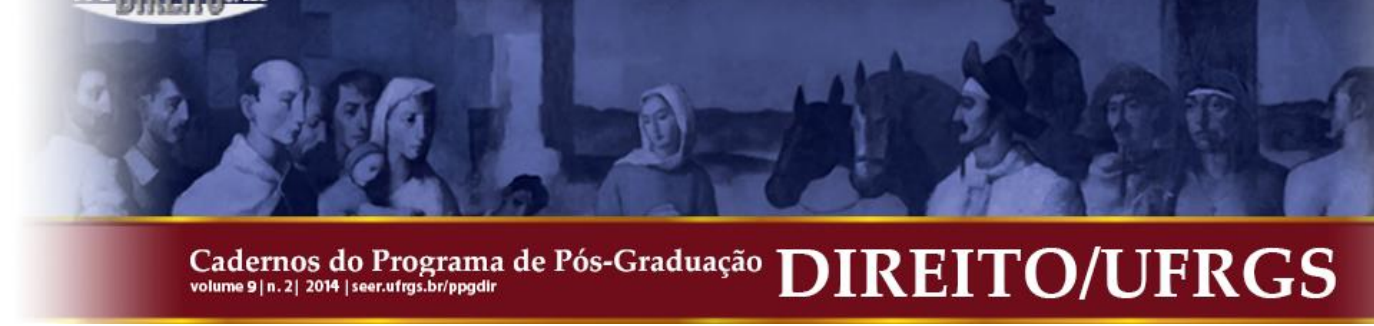

\section{CONSIDERAÇÕES FINAIS}

O Estado Constitucional e de Direito, concebido como Democrático e Republicano, não comporta tentativas de usurpação de funções entre os órgãos que compõem as funções estatais, moldadas pelo pilar da Soberania Popular. Essa determinação constitucional se dá por um respeito necessário ao princípio da Legalidade e da Reserva Legal, sustentadores da Separação das Funções Estatais, considerando a sistematicidade emanada da Constituição Brasileira de 1988.

No entanto, o instituto da súmula vinculante, ainda que com devida previsão legal, vem obtendo no mundo jurídico brasileiro foros de aceitabilidade no sentido de ter caráter coercitivo (parágrafo $3^{\circ}$, do artigo 103-A, da Constituição) sem, contudo, fazer parte do rol previsto no artigo 59 da Ordem Constitucional de 1988, estabelecendo paradoxalmente parâmetros de condutas e obrigações, o que cria um antagonismo inconsistente com os fundamentos desejados pela Comunidade Jurídica, estruturados no mencionado Projeto Constitucional, qual seja, a de um Direito e de um Estado Democrático. A problemática ora exposta é a resultante das preocupações que emergem a partir do contexto alinhavado ao longo do presente artigo, cogitações que ultrapassam, em certa medida, a crítica pura e simples ao instituto das sumulas vinculantes.

Considerando o contexto jurídico do pós-positivismo, marcado pela superação de um ordenamento jurídico desprovido de preocupações sociais, de fragilidade da racionalidade comprovada com o final da $2^{\mathrm{a}}$ Guerra Mundial e consequente reconhecimento da formulação teórica da existência de normas diferentes entre si - seja pelo método de aplicação, seja pela hipótese de incidência de seu conteúdo -, a discussão acerca da classificação normativa entre regras e princípios se faz bastante útil e atual, principalmente no tocante à justificação de decisões e à tarefa interpretativa dos juristas.

Nesse cenário, a existência das súmulas vinculantes, enquanto decisão e tarefa interpretativa, enunciados editados pelo Supremo Tribunal Federal com força normativa e, portanto, obrigatórias, chamam atenção pela importância adquirida no ordenamento jurídico brasileiro por dois principais motivos: (i) a representação do desvio da função republicanamente típica legislativa, praticada pelo Judiciário (o que suscita preocupações de 


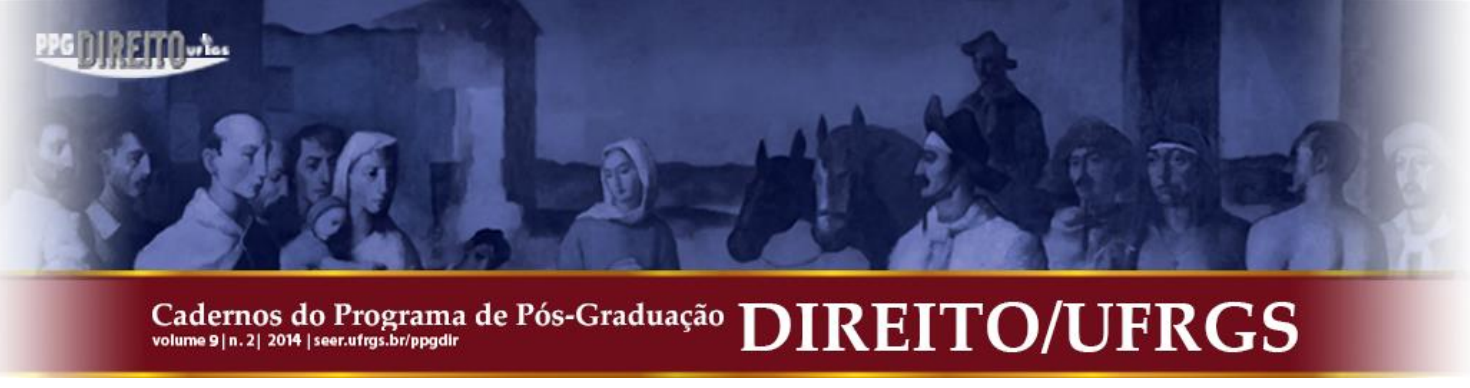

ordem de Legitimidade) e (ii) a indefinição de conteúdo, ora se comportando as súmulas como princípio, ora se comportando como regra e resultando, por vezes, numa ponderação prévia exercida no momento da atividade decisória sem, contudo, oferecer-se a devida argumentação.

Assim, tem-se a criação de enunciados verdadeiramente com peso de Lei sem, contudo, contarem com o crivo do Devido Processo Legislativo e da aprovação popular (e é disso que se fala, afinal, em uma Democracia), em clara afronta aos princípios da reserva legal e da separação das funções estatais. Não fosse suficiente a fragilidade constitucional na sua própria existência, no sentido definido por Otto Bachof, a súmula vinculante ainda representa a uniformização de entendimento resultante de uma ponderação prévia entre normas que podem se comportar de maneira diferente em outras situações não necessariamente congêneres, gerando o efeito contrário ao pretendido em termos de segurança jurídica e, por outro lado, em tentativa de se justificar como uma suposta solução para alcance da economia e celeridade processual.

Conquanto não seja usual colacionar-se excerto doutrinário no capítulo destinado às considerações finais, pede-se licença à técnica para trazer a posição de Lênio Streck exatamente a respeito da hipótese aqui alinhavada:

Com o passar dos anos, transitou em julgado a tese de que a solução para os problemas da justiça
brasileira passa, necessariamente, pela adoção do efeito vinculante das súmulas do Supremo
Tribunal Federal. Esquece-se com isto, que o problema da efetividade das decisões judiciais e da
assim denominada morosidade da justiça não serão resolvidos mediante um ataque à
funcionalidade do ordenamento ou do sistema, mas, sim, a partir de uma profunda mudança na
estrutura do Poder Judiciário e das demais instituições encarregadas de aplicar a justiça, além da
superação do paradigma epistemológico da filosofia da consciência, que pré-domina o imaginário
dos juristas. (STRECK, 2005, p. 102 e 103)

Sabe-se que o problema da constitucionalidade das súmulas vinculantes conta com bastante resistência na doutrina brasileira devido ao permissivo constitucional introduzido em 2004, que confere ao STF a competência para, literalmente, fazer as vezes de legislador (como também, em outro título paradigmático, o conteúdo da Súmula no ${ }^{\circ} 11$ ).

No entanto, mais grave é o problema prático trazido pela aplicação do instituto da súmula vinculante visualizado com o apoio da doutrina clássica de Robert Alexy, isto é, a ausência de argumentação na ponderação que se opera por ocasião da formulação do conteúdo normativo sumular, impondo uma escolha acerca de uma dada interpretação das normas constitucionais que é de observância obrigatória mas que, repita-se, não 


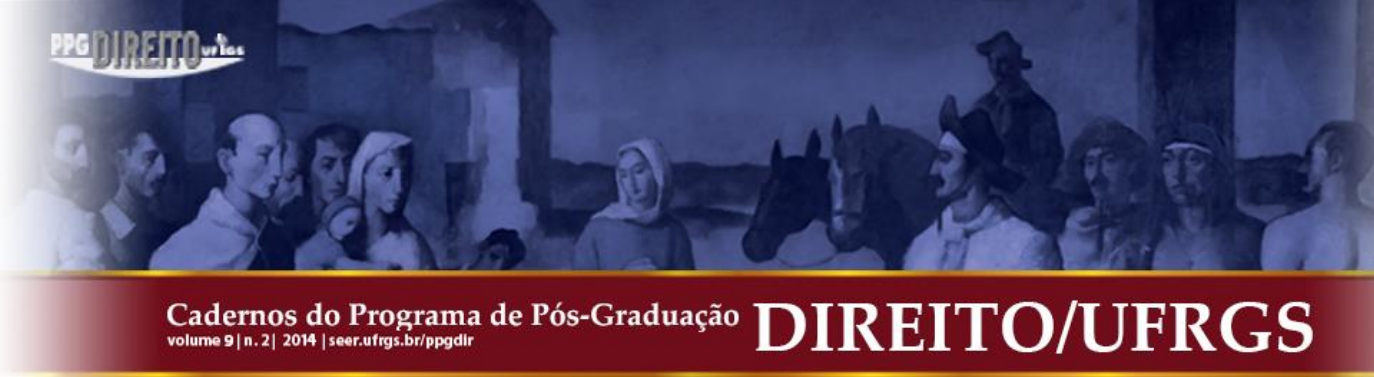

necessariamente se aplica a todas as situações como no caso da Súmula Vinculante 13, particularmente estudada neste artigo. Esse aspecto prático, que aqui se procura evidenciar como um vício decorrente da aplicação do instituto - e, sobretudo, pela inobservância do Devido Processo Legislativo - parece ultrapassar a mera violação aos princípios do Estado Democrático de Direito e se alinha à corrente teórica que defende a inconstitucionalidade das súmulas vinculantes.

\section{REFERÊNCIAS}

ALEXY, Robert. Teoria dos Direitos Fundamentais. Trad. Virgílio Afonso da Silva. São Paulo: Malheiros, 2008.

BOBBIO, Norberto. Teoria do Ordenamento Jurídico. Trad. Maria Celeste C. J. Santos. 10 ed. Brasília: Editora UNB, 1999.

BRASIL. Constituição (1988). Constituição da República Federativa do Brasil de 1988. Disponível em: <http://www.planalto.gov.br/ccivil_03/constituicao/constituicao.htm>. Acesso em: 12/06/2014.

BRASIL. Emenda Constitucional $n^{\circ} 45$, de 30 de dezembro de 2004. Altera dispositivos dos arts. $5^{\circ}, 36,52,92,93,95,98,99,102,103,104,105,107,109,111,112,114,115,125,126$, 127, 128, 129, 134 e 168 da Constituição Federal, e acrescenta os arts. 103-A, 103B, 111-A e 130-A, e dá outras providências. Disponível em: http://www.planalto.gov.br/ccivil_03/constituicao/Emendas/Emc/emc45.htm>. Acesso em: $12 / 06 / 2014$.

BRASIL. Supremo Tribunal Federal. Súmula Vinculante 13 de 2008. A nomeação de cônjuge, companheiro ou parente em linha reta, colateral ou por afinidade, até o terceiro grau, inclusive, da autoridade nomeante ou de servidor da mesma pessoa jurídica, investido em cargo de direção, chefia ou assessoramento, para o exercício de cargo em comissão ou de confiança, ou, ainda, de função gratificada na Administração Pública direta e indireta, em qualquer dos Poderes da União, dos Estados, do Distrito Federal e dos municípios, compreendido o ajuste mediante designações recíprocas, viola a Constituição Federal. Disponível em: <www.stf.jus.br>. Acesso em: 12/06/2014.

BUSTAMANTE, Thomas. Princípios, regras e conflitos normativos: uma nota sobre a superabilidade das regras jurídicas e as decisões contra legem. Direito, Estado e Sociedade, n. 37, p. 152-180, jul.-dez. 2010. 


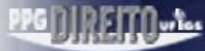 \\ Cadernos do Programa de Pós-Graduação
volume $9 \mid$ n.2| 2014 | seer.ufrgs.br/ppgdir \\ DIREITO/UFRGS}

MORAES, Alexandre de. As Súmulas Vinculantes no Brasil e a necessidade de limites ao ativismo judicial. Revista da Faculdade de Direito (USP), São Paulo, v. UNIFICADO, p. 267-265, 2012.

MORAES, Alexandre de. Constituição do Brasil interpretada e legislação infraconstitucional. 6. ed. São Paulo: Atlas, 2006.

RE, Edward D. Stare decisis. Trad. Ellen Gracie Northfleet. Revista Forense, v. 327, p. 37-42, 1990.

ROCHA, Carmen Lúcia Antunes. Sobre a súmula vinculante. Revista de Informação Legislativa, v. 34, n. 133, p. 51-64, jan./mar. de 1997. Disponível em: http://www2.senado.gov.br/bdsf/item/id/193. Acesso em 31 de julho de 2014.

ROCHA, José de Albuquerque. Súmula vinculante e democracia. São Paulo: Atlas, 2009.

STRECK, Lênio Luiz. O efeito vinculante das súmulas e o mito da efetividade: uma crítica hermenêutica. Revista do Instituto de Hermenêutica Jurídica, Porto Alegre, n.3, p. 83-128, 2005 .

STRECK, Lênio Luiz. Súmulas no direito brasileiro: eficácia, poder e função: a ilegitimidade constitucional do efeito vinculante. 2. ed. rev. e ampl. Porto Alegre: Livraria do Advogado, 1998.

Submissão: 25/09/2014

Aceito para Publicação: 18/12/2014 